\title{
Apontamentos para uma Museologia Marxista: a exposição Linha de Frente ${ }^{1}$ \\ Carlos Serrano Ferreira ${ }^{2}$ e Moana Soto ${ }^{3}$
}

\begin{abstract}
Resumo
O artigo parte da constatação da existência não clarificada de uma relação intrínseca entre o Marxismo e a Sociomuseologia. Apresentando os elementos de ligação entre os dois, principalmente pela mediação do pensamento de Paulo Freire, o artigo aponta os possíveis elementos de enriquecimento da Sociomuseologia pelo desenvolvimento aberto de uma Museologia Marxista. Segue então para a apresentação de um novo conceito de exposição dialética, construído pela analogia com os escritos de Karl Marx e Friedrich Engels, demonstrando posteriormente a primeira aplicação do mesmo na exposição Linha de Frente: Mulheres e Homens em luta pelos Direitos Humanos. Também apresenta outros conceitos que se desenvolveram nesse processo: Museologia da Urgência (contraposto ao conceito de Museologia Alienada), o de Museologia Militante e o de Museologia de Guerrilha.
\end{abstract}

Palavras-chave: Sociomuseologia; Marxismo; Dialética; Exposição; Direitos Humanos.

\footnotetext{
${ }^{1}$ A exposição teve Militantes como seu título original. Contudo, diante dos setenta anos da Declaração Universal dos Direitos Humanos (1948), o título passou a ser Linha de Frente: Mulheres e Homens em luta pelos Direitos Humanos.

${ }^{2}$ Doutorando em Ciência Política, no ISCSP da Universidade de Lisboa

${ }^{3}$,Doutoranda e Mestre em Museologia pela Universidade Lusófona de Humanidades e Tecnologias
} 


\begin{abstract}
The article starts with the verification of the existence of unclarified an intrinsic relationship between Marxism and Sociomuseology. Presenting the elements of connection between the two, mainly through the mediation of the thought of Paulo Freire, the article points out the possible elements of enrichment of Sociomuseology by the open development of a Marxist Museology. It follows then for the presentation of a new concept of dialectical exposition, constructed by the analogy with the writings of Karl Marx and Friedrich Engels, demonstrating the first application of the same in the exhibition Front Line: Women and Men fighting for Human Rights. It also presents other concepts that have developed in this process: Museology of the Urgency (opposed to the concept of Alienated Museology), the Militant Museology and the Museology of Guerrilla.
\end{abstract}

Keywords: Sociomuseology; Marxism; Dialectic; Exhibition; Human Rights.

\title{
Introdução
}

Vivemos em tempos de decadência sistêmica, de hegemonia da financeirização e de sua expressão ideológica, o neoliberalismo. Os efeitos são devastadores ecologicamente, economicamente e politicamente. Isto é válido em Portugal, aonde "vivemos tempos de empobrecimento que tocam em quase todos os setores da nossa sociedade" (Moutinho, 2017, p.181), mas no Brasil e em todo mundo, tendo cada formação social refrações da crise mundial da civilização, arrastada pela agonia do sistema capitalista. "Mas é neste tempo que temos de viver" (Moutinho, 2017, p.183). Afinal, "os homens fazem a sua própria história, mas não a fazem segundo a sua livre vontade; não a fazem sob circunstâncias de sua escolha e sim sob aquelas com que se defrontam diretamente, legadas e transmitidas pelo passado" (Marx, 2003, s.p.).

Nesta aceleração da crise, em trinta anos que significaram "a diferença entre uma sociedade que não era regida pelos princípios do neoliberalismo para uma sociedade das inevitabilidades e das austeridades" (Moutinho, 2017, p.183), o 
Movimento Internacional para uma Nova Museologia (MINOM) tem sido um espaço de resistência, fazendo seu

caminho[,] que se fez caminhando, confrontando nova com velha museologia, onde a luta de classes se manifestou com grande vigor, favorecendo iniciativas portadoras de mudança, destruindo esperanças e provocando renúncias, seleccionando as pessoas e os postos de trabalho, pela afiliação ou não, às referências culturais de cada um e de cada uma. (Moutinho, 2017, p.183).

Caminho que trouxe novas práticas museológicas, com diferentes modelos de nova museologia (Moutinho, 2017) e também organizacionais, que abriram caminho para uma nova perspectiva com a Sociomuseologia, que "acabaria de levar a museologia entendida como era até então como uma técnica, para um novo lugar no seio das ciências sociais nas quais a dialéctica se estabelece entre as formas de fazer e a compreensão daquilo que foi a sua prática, nos seus contextos, nas suas contradições" (Moutinho, 2017, p.185).

A expressão desse processo de decadência ganhou o nome, não só eufemístico - afinal, imperialismo já não é mais bemquisto como o fora até princípios do século $X X$ - mas também de signo apologético: globalização. $E$, frente a este, como dizia já há mais de dez anos Pierre Mayrand (2007) ${ }^{4}$,

Hoje, o rolo compressor da globalização obriga mais uma vez o museólogo a juntar a sua energia ao apelo das populações e organizações dedicadas à transformação do quadro museal num Fórum Ágora - Cidadão, e obriga-o também a se colocar no campo do altermundismo com uma posição didática,

\footnotetext{
${ }^{4}$ Apud Chagas (2011, p.6).
} 
dialética, capaz, pelas energias vitais que gera, de fazer progredir o diálogo entre os povos.

Não foi por acaso que Moutinho (2017) e Mayrand (2007) utilizaram em seus textos expressões como 'luta de classes', 'contradições' e 'dialética', ou que Judite Primo (2014) reconheça o museu enquanto 'aparato ideológico do Estado', o que faz eco ao conceito do marxista francês Louis Althusser. Há aqui a influência clara de uma concepção científica-política de mundo, que está subjacente às reflexões da Nova Museologia, que é o marxismo. Em alguns momentos ela se apresenta de forma direta, como a aplicação por Moutinho (1989) da economia política marxista ao processo de produção de um museu, em sua busca por embasar um conceito de museologia para além da ação museal. É sintomático o recurso a essa perspectiva ao se avançar na procura do "denominador comum a todas as instâncias e manifestações do processo museológico" (Moutinho, 1989, p.88).

Contudo, a maioria dos materiais não explicita esta relação, que permanece assim como uma presença, mas uma presença oculta. Parafraseando Karl Marx e Friedrich Engels no panfleto político que mais sucesso fez na história, o Manifesto do Partido Comunista, de 1848, anda um espectro pela Sociomuseologia - o espectro do Marxismo.

Essa influência assume este aspecto espectral, pois é indireta, ela se materializa através de outro corpus teórico que foi fundamental para a gênese do que se converteria no MINOM: o pensamento de Paulo Freire (Soto, 2017). Como defende corretamente em nossa opinião - Primo (2014, p.7):

existe uma relação muito explícita entre 0 Movimento de Nova museologia (que surgiu na última metade do século XX), com os novos modelos de educação para a cidadania, os processos de transformação política, social e cultural que ocorreu na generalidade dos países ocidentais. Essas 
transformações contribuíram para que os museus seguissem o caminho para a sua aproximação do modelo de fóruns, sítios de encontros, de diálogos, de debates e de ações museológicas comprometidos com a memória, com o património e com a mudança social.

Como esboçou Moana Soto $(2017$, p.8), coube a Paulo Freire um

papel de destaque na configuração do movimento da Nova Museologia, quando se transferiu ao campo museal suas teorias sobre educação como prática de liberdade e conscientização, que se consubstanciou na visão de que o museu pode ser também uma ferramenta de construção de identidade e de cidadania $^{5}$.

Um elemento que aponta para isto, além do recorrente e expresso reconhecimento por parte de figuras centrais do MINOM, como Hugues de Varine ${ }^{6}$, Mário Chagas e Mário Moutinho, ou na indicação dele para presidir a Mesa Redonda de

\footnotetext{
${ }^{5}$ Neste momento, Moana Soto desenvolve investigação no sentido de apontar a influência de Paulo Freire na Nova Museologia, pois esta influência na "Museologia contemporânea é uma constatação, mas ainda não foi alvo de estudos aprofundados" (Cândido, 2003, p.47).

6 "O papel exercido pelo pensamento de Paulo Freire nas novas experiências de museus foi marcante, principalmente, pela transformação do homem-objeto em homem-sujeito, como assinalou Hugues de Varine-Bohan em 1979, período em que exercia a direção do ICOM. A partir desta conceção, Varine formulou uma importante metáfora nesta mudança de paradigma dos museus e da própria Museologia, "o museu como finalidade, o museu como objetivo, é a universidade popular, a universidade para o povo através dos objetos. O que numa universidade normal é a linguagem das palavras e em última instância a linguagem dos sinais escritos, no caso do museu converte-se em linguagem dos objetos, do concreto". (Salvat, 1979, p.19)" (Soto, 2017, p.7).
} 
Santiago do Chile, de 1972, ainda que não tenha se concretizado devido ao veto pelo delegado brasileiro da UNESCO.

Esta relação entre a Nova Museologia, Paulo Freire e o Marxismo é obscurecida pela vaga contra-revolucionária em curso desde o final das experiências do chamado socialismo realmente existente, com a desagregação da União Soviética em 1991. O discurso do fim da história (da luta de classes), que recebeu sua forma mais acabada em Francis Fukuyama e seu livro intitulado, exatamente, O fim da história e o último homem ${ }^{7}$, levou a um refluxo das concepções dos setores progressistas. Estes retrocederam em seu entendimento do mundo - muitos abandonam o marxismo e adotam uma versão de "esquerda" do liberalismo - bem como em suas bandeiras e programas assumindo versões reformistas tão "novas" como o século XIX. Em lugar de classes, cidadãos. Em lugar de luta de classes, conciliação. Em lugar de revolução, reforma (ainda que o sistema tenha fechado o caminho para elas). Em lugar de democracia proletária ou popular, a democracia liberal (ainda que sem se enunciar desta maneira). O máximo que se enxergou como objetivo era a (utópica) democratização da democracia (liberal), uma impossibilidade histórica, tendo em vista que esta só sobrevive com a fusão a um elitismo que afasta de si os temores burgueses frente às massas ${ }^{8}$. Isto ainda que vitórias conjunturais

7 Que recebeu uma resposta imediata, mostrando a não-novidade deste discurso, em Perry Anderson (1992), O fim da história - de Hegel a Fukuyama.

${ }^{8}$ Cf Miguel (2002). Neste artigo, o professor de Ciência Política da Universidade de Brasília (UnB), diz "Já na democracia contemporânea, o povo é condenado à quase passividade. Exerce sua "soberania" de tempos em tempos, no momento da eleição. Ainda assim, limita-se a escolher entre as opções que lhe são apresentadas por grupos organizados, já que o próprio sentido da representação política foi alterado, destinando ao eleitor um papel reativo (ver Bourdieu, 1990:188). Parte dessa distância entre as duas faces da democracia, a clássica (ou etimológica) e a atual, pode ser creditada ao fato de os regimes democráticos contemporâneos serem entendidos e vividos a partir de pressupostos - sobre a natureza humana e sobre a organização das sociedades 
na democratização tenham ocorrido, para depois serem revertidas ou esvaziadas de conteúdo ${ }^{9}$. A luta pela

- emprestados de uma corrente teórica que nasceu para afirmar a impossibilidade das democracias: a chamada "teoria das elites". Os fundadores dessa corrente, Mosca, Pareto e Michels, não escondiam sua oposição aos movimentos democráticos e socialistas presentes na virada do século XIX para o XX. Suas obras revelam a apreensão com a atuação desses movimentos e buscam demonstrar que seus objetivos igualitários eram ilusórios. Segundo eles, sempre vai haver desigualdade na sociedade, em especial a desigualdade política. Isto é, sempre existirá uma minoria dirigente e uma maioria condenada a ser dirigida, o que significa dizer que a democracia, enquanto "governo do povo", é uma fantasia inatingível. Pois é exatamente esta visão que, sobretudo a partir da teoria de Schumpeter, publicada nos anos 1940, se torna a base da tendência dominante da teoria democrática - e penetra profundamente na concepção corrente sobre a democracia." (Miguel, 2002, p.485). Afinal, democracia e capitalismo são incompatíveis. Essa nova interpretação de democracia, que é hoje dominante, vem para tentar resolver um grande problema do campo capitalista no pós-Segunda Guerra Mundial, que era "a demonstrar que existia uma verdadeira democracia, apesar da evidente ausência do governo do povo. Ao redefinir a democracia de forma a excluir o que antes era seu principal critério, a teoria de Schumpeter se prestava bem a este fim. Assim, embora Schumpeter e os schumpeterianos gostem de se apresentar como neutros e descritivos, em contraste com a visão "ideológica" dos críticos dos regimes políticos ocidentais, sua empreitada intelectual possuiu um significativo caráter justificador do status quo"." (Miguel, 2002, p.499).

${ }^{9}$ De facto, o espaço para reformas e democratizações é cada vez mais reduzido, e as vitórias são revertidas rapidamente. Note-se, no entanto, que isto não nega o papel histórico dos setores populares na democratização, contra a resistência histórica da burguesia e dos outros setores proprietários associados. Como diz Valério Arcary, “Um razoável consenso histórico já se estabeleceu reconhecendo o papel decisivo das classes trabalhadoras e suas organizações na luta democrática, desde a primeira vaga de conquista de direitos políticos, encabeçada pelos cartistas ainda em meados do século XIX [...]. É sempre bom lembrar que o sufrágio universal só se estendeu no Ocidente, ao final do século XIX, depois de um século de difíceis lutas e combates dos trabalhadores (o direito feminino de voto é ainda mais recente). Além disso, a experiência do século $[X X]$ parece ensinar que a tendência ao bonapartismo ou ao fascismo, não se explica por uma patologia especial das sociedades italiana, alemã, espanhola ou portuguesa: tem raízes históricas inseparáveis da crise capitalista. É um fenômeno crônico da contra-revolução burguesa." (Arcary, 2006, p.128). 
democratização da democracia é uma luta que só é viável se assumir um caráter anticapitalista, pois é o capitalismo o principal obstáculo à democracia, se não entendemos esta apenas como um método de circulação de elites, mas na fórmula clássica de Abraham Lincoln (1863) em seu discurso de Gettysburg: "governo do povo, pelo povo, para o povo".

Este fenômeno é explicável tendo em vista o momento que vivemos. Lénine (1984), em outra conjuntura de retrocesso, após a derrota da primeira Revolução Russa de 1905, e cinco anos antes da Revolução de Outubro de 1917, escrevia:

Utopia é uma palavra grega: «u» em grego quer dizer "não», "topos» quer dizer lugar. Utopia é um lugar que não existe, uma fantasia, uma invenção, uma fábula.

A utopia em política é uma espécie de aspiração que não é possível concretizar, nem no presente nem no futuro, uma aspiração que não assenta nas forças sociais e que não se apoia no crescimento, no desenvolvimento das forças políticas, das forças de classe.

Quanto menos liberdade há num país, quanto mais exígua é a manifestação da luta aberta das classes, quanto mais baixo é o nível de instrução das massas, com tanto mais facilidade surgem normalmente as utopias políticas e mais tempo se mantêm.

Os marxistas são "hostis a todas as utopias [Grifo no Original]" (Lénine, 1984) e por isso não podem se quedar nestes limites. Contudo, podem compreender, como fez o próprio Lénine, as causas desses retrocessos, ainda que não devam se acomodar às mesmas. Um dos papéis centrais do marxismo é exatamente expor essas causas e, principalmente, mostrar os fenômenos que estão por trás do véu ideológico. Nesse sentido, 
trabalha Soto (2017, p.8), ao mostrar que são as vagas revolucionárias enquanto "substrato histórico[,] que gerou a Nova Museologia [e] gerou também o pensamento de Paulo Freire, por isso ambas se aproximam e se identificam, tendo sido decisiva a influência deste autor nos princípios que embasaram esse movimento". Se elas são gestadas na "terceira vaga revolucionária (1944/1964) do século XX, que terá como principal resultado, além da derrota do nazifascismo, a descolonização afro-asiática" (Soto, 2017, p.1), elas germinarão durante a quarta vaga revolucionária ${ }^{10}$. Esta

terá como um dos epicentros a França e o outro a América Latina, respetivamente os núcleos de pensamento da Nova Museologia e de Paulo Freire. Também trará uma série de outros debates, como a questão ecológica, feminista e racial. Há um elo ainda subjacente, pois com "o chamado 'maio de 1968', movimento de rebeldia dos estudantes universitários, aliado à repressão da 'primavera de Praga' pela União Soviética, grande número de intelectuais de esquerda, antes simpatizantes da linha ideológica russa, aderiram ao maoísmo." (Saviani, 2008, p.334).

\footnotetext{
10 "A quarta onda da revolução mundial foi a mais internacional de todas, até hoje, e ameaçou seriamente a dominação imperialista. [...] Começou, também, na Europa - Maio 68 francês, e Outono quente italiano - e na Ásia (ofensiva no Vietnam e internacionalização no Camboja, derrota militar portuguesa nas colônias africanas), e chegou a ter uma refração na América Latina, onde o movimento estudantil se levantou pelas liberdades democráticas (México e Brasil em 1968), e o movimento operário se lançou a ações de massas combativas (Cordobazo argentino em 1969, revolução chilena 1970/73). A articulação entre os movimentos de luta em diferentes continentes não avançou. Um por um, derrota atrás de derrota, os três focos foram sendo destruídos." (Arcary, s.d., s.p.).
} 
E, o pensamento maoísta será marcante não só no pensamento dos intelectuais e da esquerda francesa, mas também no próprio Paulo Freire, como fica patente nas suas referências em Pedagogia do Oprimido (1968) e em Ação Cultural para a Liberdade (1970), em que se vê a clara influência da Revolução Cultural Chinesa (que se desenrola entre 1966 e 1976). Ou, até mesmo, pela influência indireta do marxismo e do maoísmo via a Teologia da Libertação, movimento radical católico latino-americano. É esse substrato histórico que permite entender o contexto de formulação da política da Nova Museologia e Paulo Freire. Se for possível afirmar que "a pedagogia libertadora de Freire é o correlato, em educação, da 'teologia da libertação'”' (Saviani, 2008, p.333), poderíamos dizer que a Nova Museologia é o seu correlato museológico, uma 'museologia da libertação' ${ }^{11}$. (SOTO, 2017, p.4).

Porém, por esta influência ter tido um caráter espectral e, devido à atual conjuntura refratária ao marxismo, o quanto de marxismo subjaz na Sociomuseologia não está clarificado. De facto, é necessário que se revele as bases marxistas da Sociomuseologia por trás das mediações que se construíram. Isto

${ }^{11}$ Esta idéia de museologia da libertação foi apresentada por “Odalice Priosti [...] (durante o III Encontro de Ecomuseus e Museus Comunitários, no Rio de Janeiro, em setembro de 2004) [...] por extensão dos princípios da teologia latinoamericana da libertação por um lado e por referência à educação como prática da liberdade (Paulo Freire). Nessa abordagem, claramente política no sentido mais nobre da palavra, trata-se de utilizar o museu e a educação patrimonial para conscientizar os membros das comunidades, torná-los capazes de autonomia e de iniciativa, prepará-los para uma participação dinâmica no desenvolvimento de seu território e em geral na vida pública" (Varine-Bohan, 2005, s.p.). 
não só por uma questão de honrar às fontes originárias, o que seria legítimo, mas atenderia apenas uma necessidade intelectual. Nada menos marxista que a defesa de um retorno às fontes do marxismo, proposta mais própria da exegética teológica, como se os livros dos fundadores do marxismo fossem livros sagrados ${ }^{12}$. A importância é de outra natureza. Assumir o marxismo subjacente à Sociomuseologia, fazendo-o aflorar, retirando-o dos subterrâneos do campo, cumpre tanto a função de ajudar a resolver impasses conceituais existentes, como possibilita por sua apreensão consciente dos conceitos e métodos a elaboração de novas perspectivas e a supressão de lacunas ainda existentes.

Além, é claro, de recolocar ao serviço de que projeto histórico deve estar a museologia, os museus e os museólogos, desvencilhando as perspectivas progressistas na museologia de quaisquer ilusões ideológicas. Ou seja, significa ligar ao projeto de uma Nova Museologia um projeto claro de uma Nova Sociedade, o que não a retiraria do campo de uma ciência, mas ainda que atraindo o ódio de classe, lhe daria um caráter ainda mais científico, pois mais consciente ${ }^{13}$. Pois, é claro que

12 Segundo Lukács (2003, p.64), “o marxismo ortodoxo não significa [...] um reconhecimento sem crítica dos resultados da investigação de Marx, não significa uma 'fé' numa ou outra tese, nem a exegese de um livro 'sagrado'."

13 "A doutrina de Marx suscita em todo o mundo civilizado a maior hostilidade e o maior ódio de toda a ciência burguesa (tanto a oficial como a liberal), que vê no marxismo uma espécie de 'seita perniciosa'. E não se pode esperar outra atitude, pois, numa sociedade baseada na luta de classes não pode haver ciência social 'imparcial'. De uma forma ou de outra, toda a ciência oficial e liberal defende a escravidão assalariada, enquanto o marxismo declarou uma guerra implacável a essa escravidão. Esperar que a ciência fosse imparcial numa sociedade de escravidão assalariada seria uma ingenuidade tão pueril como esperar que os fabricantes sejam imparciais quanto à questão da conveniência de aumentar os salários dos operários diminuindo os lucros do capital" (Lénine, 2000, s.p.). 
A museologia social, [...] está comprometida com a redução das injustiças e desigualdades sociais; com o combate aos preconceitos; com a melhoria da qualidade de vida coletiva; com o fortalecimento da dignidade e da coesão social; com a utilização do poder da memória, do patrimônio e do museu a favor das comunidades populares, dos povos indígenas e quilombolas, dos movimentos sociais, incluindo aí, o movimento LGBT, o MST e outros (Chagas \& Gouveia, 2014, p.17).

Porém, a questão colocada é como unificar estas lutas, como apresentar uma alternativa para além das perspectivas isoladas, para as demandas particulares, de diversos níveis, do identitário ao econômico; do local ao nacional e internacional; clarificando conceitos - como, por exemplo, desenvolvimento ou social - que podem dizer muito, e ao mesmo tempo não dizer nada se não forem marcados por um corte claro, classista. Para isso é preciso ir além da representação e expressão dos excluídos, oprimidos e explorados, ainda que isto seja um passo fundamental, como reler o passado superando a memória do poder (Chagas, 2002) e a história ideológica (Chauí, 2008) ${ }^{14}$, e construindo uma nova

\footnotetext{
14 “Porque a ideologia não tem história, mas fabrica histórias imaginárias que nada mais são do que uma forma de legitimar a dominação da classe dominante, compreende-se por que a história ideológica (aquela que aprendemos na escola e nos livros) é sempre uma história narrada do ponto de vista do vencedor ou dos poderosos. Não possuímos a história dos escravos, nem a dos servos, nem a dos trabalhadores vencidos - não só suas ações não são registradas pelo historiador, mas os dominantes também não permitem que que restem vestígios (documentos, monumentos) dessa história. Por isso, os dominados aparecem nos textos dos historiadores sempre a partir do modo como eram vistos e comrpeendidos pelos próprios vencedores.

O vencedor ou poderoso é transformado em único sujeito da história, não só porque impediu que houvesse a história dos vencidos (ao serem derrotados, os vencidos perderam o 'direito' à história), mas simplesmente porque sua ação
} 
representação do passado e mesmo do presente mais inclusiva e democrática. Mas, é necessário ligar a luta pela retificação das fantasmagorias do passado, estas sempre ao serviço do controle e justificação do presente $^{15}$, à luta pela superação do mesmo e a realização de um futuro possível melhor, ainda que não garantido. Para isso é preciso o entendimento e o desvelamento dos limites atuais e as possibilidades de superação intrinsecamente postas nestes próprios limites. Para isto, não se inventou até agora nada mais avançado que o marxismo.

Sobre as nossas interpretações marxistas para as possibilidades de superação de alguns impasses conceituais, e a precisão de outros, por questão de espaço e da necessidade de aprofundamento serão relegadas para futuros artigos. Neste, nos centraremos basicamente em expor um conceito, o de exposição dialética, que pode colaborar para o desenvolvimento de uma Museografia Social, bem como quatro conceitos que emergiram com este, o de Museologia da Urgência (contraposto ao conceito de Museologia Alienada), o de Museologia Militante e o de Museologia de Guerrilha. Eles surgiram em estado prático e foram na prática de realização de uma exposição, Linha de Frente: Mulheres e Homens em luta pelos Direitos Humanos, ganhando um estatuto teórico. Para isso, principiaremos com a apresentação do primeiro conceito, já mais amadurecido, e depois partiremos para a apresentação do caso específico, e

histórica consiste em eliminar fisicamente os vencidos, ou, então, se precisa do trabalho deles, elimina sua memória, fazendo com que se lembrem apenas dos feitos dos vencedores. [...] Não há direito à memória para o negro. Nem para o índio. Nem para os camponeses. Nem para os operários.

[...] Graças a esse tipo de história, a ideologia pode manter sua hegemonia mesmo sobre os vencidos, pois estes interiorizam a suposição de que não são sujeitos da história, mas apenas seus pacientes." (Chauí, 2008, pp.116-118).

15 No futuro distópico e fascista da obra de George Orwell, 1984, o lema do Partido era "Quem controla o passado, [...] controla o futuro: quem controla o presente controla o passado." 
neste apenas esboçaremos os outros quatro conceitos, que ainda serão desenvolvidos com profundidade em futuros artigos.

Exposição dialética

Qual o objetivo da exposição dialética? É ser parte de um processo mais amplo, de crítica da ideologia pelo discurso da ação e pela ação do discurso, ambas de natureza popular:

Quem e o que pode desmantelar a ideologia? Somente uma prática política nascida dos explorados e dominados e dirigida por eles próprios. Para essa prática política é de grande importância o que chamamos de crítica da ideologia, que consiste em preencher as lacunas e os silêncios do pensamento e discurso ideológicos, obrigando-os a dizer tudo que não está dito, pois desta maneira a lógica da ideologia se desfaz e se desmancha, deixando ver o que estava escondido e assegurava a exploração econômica, a desigualdade social, a dominação política e a exclusão cultural. (Chauí, 2008, p.118).

De certa forma, o que se busca é reverter os resultados que a tendência ao culto da memória do poder ${ }^{16}$, bem como o culto do próprio poder, traz à museologia. Pois, apesar da negação da transformação social sempre presente no pensamento burguês e por isso, do próprio poder enquanto poder burguês - os setores dominantes tratam de um futuro, ainda que seja o da eternização do presente, e por isso, eles podem celebrar o presente e o futuro, contanto que essas interpretações estejam dentro dos

16 “Os museus celebrativos da memória do poder - ainda que tenham tido origem, em termos de modelo, nos séculos XVIII e XIX - continuaram sobrevivendo e multiplicaram-se durante todo o século XX. Aqui não se está falando de instituições perdidas na poeira do tempo; ao contrário, a referência incide em modelos museológicos que, superando as previsões apocalípticas de alguns especialistas, sobrevivem e continuam deitando regras." (Chagas, 2002, pp. 62). 
limites dos interesses da classe dominante. E esta celebração do poder burguês organiza toda a perspectiva da museologia tradicional (burguesa):

A tendência para a celebração da memória do poder é responsável pela constituição de acervos e coleções personalistas e etnocêntricas, tratadas como se fossem a expressão da totalidade das coisas e dos seres ou a reprodução museológica do universal, como se pudessem expressar o real em toda a sua complexidade ou abarcar as sociedades através de esquemas simplistas, dos quais o conflito é banido por pensamento mágico e procedimentos técnicos de purificação e excludência. (Chagas, 2002, pp.63-64).

Porém, é mais do que exorcizar o conflito, pois o conceito de conflito - e o conflito em si - é menos problemático para a burguesia - e classes dominantes anteriores - do que o conceito de contradição - e a própria contradição em si -, que é parte constitutiva da dialética. O conflito não tem uma natureza ontohistórica, podendo ser produzido por contingências, confusões e mesmo mal-entendidos. A contradição não. O conflito pode se estabelecer entre entes sem que isto seja componente obrigatória da relação entre eles, enquanto a contradição é o que cria os dois pólos da mesma relação. Podem surgir conflitos entre indivíduos de uma mesma classe ou entre classes exploradas, por exemplo, mas estes conflitos não espelham uma contradição necessária entre as mesmas. O conflito pode ocorrer, como pode não ocorrer, e ainda assim estes entes continuarão a existir. Já a sociedade capitalista é a expressão da contradição inescapável entre capitalistas e proletários. Essa contradição é inescapável, pois só existe o capitalista - o proprietário dos meios de produção e que vive do trabalho alheio - se existir o proletário privado dos meios de produção e que vive da venda de sua força 
de trabalho. O motor do capitalista é maximizar seus lucros, que só podem avançar pela redução dos salários do outro, o proletário, que busca no capitalismo ampliar os seus salários à custa do lucro capitalista. Logo, a contradição é permanente e componente dos dois pólos. Independente das motivações e "boas" intenções que elementos de cada classe possam ter, a existência das classes mesmas exigem a luta de classes e, por isso, desde que estas surgem a partir de certo momento, "a história de toda a sociedade até aqui é a história de lutas de classes" (Marx \& Engels, 1997).

O materialismo dialético, a grande criação e método de estudo e ação do marxismo, demonstra que a contradição é a substância da realidade, e a superação de contradições em novas contradições, em uma espiral sob a qual se ergue e move a história, é a natureza última da matéria e, por conseguinte, da idéia, desdobramento reflexivo da primeira. Já afirmava Engels (1877, s.p.) que "o movimento é o modo de existência da matéria", e isto se relaciona com a contradição, pois "em termos categoriais, a origem do movimento e do desenvolvimento dos entes e dos fenômenos em geral reside, precisamente, nas contradições que internamente os constituem." (Barata-Moura, 2012, p.302). Contradição, movimento, história, devir: tudo o que compõe a natureza e a sociedade contraria os interesses burgueses que necessitam se apresentar como o estágio final, a paragem final do comboio histórico. Isto é o oposto ao marxismo. Karl Marx (2006, s.p.), inclusive, afirma que

no que me diz respeito, não me cabe o mérito de ter descoberto nem a existência das classes na sociedade moderna nem a sua luta entre si. Muito antes de mim, historiadores burgueses tinham exposto o desenvolvimento histórico desta luta das classes, e economistas burgueses a anatomia económica das mesmas. 
Mas, entre o que ele próprio afirma que fez de novo foi "demonstrar que a existência das classes está apenas ligada a determinadas fases de desenvolvimento histórico da produção [Grifos no original.]" (Marx, 2006, s.p.), ou seja, que as classes são, como tudo, construções históricas passageiras, não votadas à eternidade, tal qual os sistemas que as engendram, como o capitalismo. E a contradição está intrinsecamente ligada a outra categoria central da dialética: a totalidade ${ }^{17}$.

É verdade que a burguesia pós-Revolução Francesa utilizouse da memória como arma contra a antiga classe dominante, penetrando "com ou sem sutileza nas escolas, nos museus, nas bibliotecas, nos arquivos, na produção artística, religiosa, filosófica e científica" (Chagas, 2002, p.47), mas rapidamente, a partir do aparecimento do proletariado em cena, virará a memória contra seu novo e mais mortal inimigo. Entre os museus que constrói, a burguesia francesa erigirá o Museu do Louvre, que servirá para "exalta[r] a civilização, realiza[r] o elogio da nação e destaca[r] a sua participação no concerto universal como herdeira dos valores clássicos ocidentais" (Chagas, 2002, p.48). Este exemplifica de facto, como nenhum outro, a pretensão ideológica da nova classe dominante, pois serve para a burguesia

17 Ainda que não sejam as únicas categorias da dialética, totalidade e contradição são as duas "que, porventura, melhor nos habilitam e ajudam a compreender e a determinar, nos seus diferentes níveis e instâncias, a dialéctica." (Barata-Moura, 2012, p.27). Segundo Lukács (2003, pp.105-106), "Não é o predomínio dos motivos econômicos na explicação da história que distingue de maneira decisiva o marxismo da ciência burguesa, mas o ponto de vista da totalidade. A categoria da totalidade, o domínio universal e determinante do todo sobre as partes constituem a essência do método que Marx recebeu de Hegel e transformou de maneira original no fundamento de uma ciência inteiramente nova. [...] A ciência proletária é revolucionária não somente pelo fato de contrapor à sociedade burguesa conteúdos revolucionários, mas, em primeiro lugar, devido à essência revolucionária do seu método. O domínio da categoria da totalidade é o portador do princípio revolucionário na ciência [Grifos no original]". 
vitoriosa elevar sua posição e civilização ao nível do universal. E é nesse patamar que a resposta popular deve se dar: na escala universal. O capitalismo é o primeiro sistema-mundo, a primeira civilização universal, e por isso, a sua superação só pode se dar nessa escala, nunca numa menor. É claro que essa contraposição não se dará imediatamente na escala universal, mas é apontando para este sentido que deve ir. Logo, as articulações locais devem sempre ligar-se a uma perspectiva global, estabelecendo as ligações entre os elementos, entre as diversas contradições. É preciso apontar como todas estas, sejam secundárias ou terciárias - não no sentido imediato dos indivíduos, pois para o seu sofrimento estas podem ser a principal, mas do ponto de vista histórico, ou seja, o ponto de vista da luta universal - são momentos da contradição principal entre Capital e Trabalho, entre Relações de Produção Capitalistas privadas e Forças Produtivas cada vez mais socializadas.

Pode se dizer, tendo em vista o caráter cada vez mais reduzido, ínfimo, dos proprietários, e o caráter cada vez mais universal dos não-proprietários, e da ameaça cada vez mais universal que a manutenção da propriedade sob o controle desse contingente cada vez mais reduzido de burgueses traz, que há uma identificação entre os interesses da Humanidade - inclusive a sua sobrevivência - com os interesses das classes dominadas, cada vez mais tornadas em seu conjunto em proletariado. Neste sentido, direitos humanos tornam-se cada vez mais, não no discurso aparente do Direito Burguês, mas na concretude dos factos, direitos proletários. E neste aspecto será pensada a exposição que relataremos mais adiante.

É ao expor a totalidade contraditória da sociedade, “[...] a partir de uma análise correcta (e concreta) das contradições de que a totalidade se tece que resulta então possível, não só compreendê-la, mas também intervir eficazmente sobre ela, no sentido da sua transformação" (Barata-Moura, 2012, p.313). Foi para expor as contradições da sociedade capitalista que Marx se 
dedicou à exposição dialética dessa sociedade em sua opus magnum, $O$ Capital. A exposição dialética enquanto técnica museográfica não pode ser, no entanto, substitutiva da ação política, mas deve ser complementar à mesma, associada à mesma, ligada aos movimentos sociais, e mesmo apropriadas pelos movimentos contestatórios como instrumento seu - o que entraria no campo da democratização do fazer museológico, que excede o âmbito de análise deste artigo. A exposição dialética busca então desconstruir o discurso ideológico burguês pela apresentação científica da totalidade das contradições existentes, das suas interligações e interpenetrações, bem como de seu caráter histórico e superável.

Para isso, propomos que a exposição dialética na museologia siga em paralelo o método de investigação-exposição dialético expresso na obra escrita de Marx e Engels. O que necessita, no entanto, de adequação formal e técnica tendo em vista que na aplicação museológica se tratarão de exposições que se escreverão em sua maioria não com o recurso à escrita, mas com recursos aos objetos museológicos, sendo a escrita apenas acessória.

Em seu método Marx diferencia dois momentos: o da investigação e o da exposição:

Certamente que o modo de exposição se tem de distinguir formalmente do modo de investigação. $A$ investigação tem de se apropriar do material em pormenor, de analisar as suas diversas formas de desenvolvimento e de seguir a pista do seu vínculo interno. Somente depois de completado este trabalho pode o movimento real ser exposto em conformidade. Se se consegue isto e se a vida do material se reflecte; então, idealmente [ideell], poderá parecer que se está perante uma construção a priori. (Marx, 1990, s.p.) 
Isto tem uma razão, que é evitar quer sejam as mistificações idealistas, que partem das idéias - abstrações do concreto material - e as tomam por autônomas e determinantes do real Deus, o Estado, Civilização, Fortuna, etc, a depender do viés mais racionalista ou irracionalista desse idealismo - como as perspectivas empiristas, típicas da ciência burguesa, em particular da economia burguesa, que analisam o concreto em sua aparência, dissociando os seus elementos. Há assim que partir do concreto empírico, estudá-lo profundamente, a partir de uma sucessiva operação de abstração - separação dos seus elementos componentes - e de síntese - retorno à totalidade, agora já reconstruída de forma nova, em forma de um concreto pensado - aonde se superam as aparências pela percepção das ligações e contradições constitutivas de suas relações. Afinal, "o concreto é concreto porque é a síntese de múltiplas determinações, portanto, unidade da diversidade" (Marx, 2011, pp.77-78). De facto, o movimento de investigação é partir do material, do concreto efetivo, como o fizeram os economistas políticos burgueses:

Se consideramos um dado país de um ponto de vista político-econômico, começamos com sua população, sua divisão em classes, a cidade, o campo, o mar, os diferentes ramos de produção, a importação e a exportação, a produção e o consumo anuais, os preços das mercadorias etc.

Parece ser correto começarmos pelo real e pelo concreto, pelo pressuposto efetivo, e, portanto, no caso da economia, por exemplo, começarmos pela população, que é o fundamento e o sujeito do ato social de produção como um todo. Considerado de maneira mais rigorosa, entretanto, isso se mostra falso. A população é uma abstração quando deixo de fora, por exemplo, as classes das quais é constituída. Essas classes, por sua vez, são uma palavra vazia se 
desconheço os elementos nos quais se baseiam. P. ex., trabalho assalariado, capital etc. Estes supõem troca, divisão do trabalho, preço etc. O capital, p. ex., não é nada sem o trabalho assalariado, sem o valor, sem o dinheiro, sem o preço etc. Por isso, se eu começasse pela população, esta seria uma representação caótica do todo e, por meio de uma determinação mais precisa, chegaria analiticamente

a conceitos cada vez mais simples; do concreto representado [chegaria] a conceitos abstratos [Abstrakta] cada vez mais finos, até que tivesse chegado às determinações mais simples. [...]Os economistas do século XVII, p. ex., começam sempre com o todo vivente, a população, a nação, o Estado, muitos Estados etc.; mas sempre terminam com algumas relações determinantes, abstratas e gerais, tais como divisão do trabalho, dinheiro, valor etc., que descobrem por meio da análise. Tão logo esses momentos singulares foram mais ou menos fixados e abstraídos, começaram os sistemas econômicos, que se elevaram do simples, como trabalho, divisão do trabalho, necessidade, valor de troca, até o Estado, a troca entre as nações e o mercado mundial.

Contudo, este primeiro movimento, ainda que importante na investigação, não é o definitivo. Pois, se ficar neste movimento de abstração corresse o risco de recair nesse empirismo - que disseca a totalidade como se disseca um cadáver, perdendo-se as relações que tornam um ser mais que a mera soma de suas partes - que desaguou no positivismo, e tornar as partes entes independentes; ou em sistemas idealistas, que tomam estes conceitos em abstrato não como reflexo do empírico no pensamento, mas em sua realidade. Há que se retornar ao concreto, mas estabelecendo as relações entre os conceitos - 
enquanto expressões refletidas na mente de elementos da realidade - verificando suas contradições e relações na concretude histórica. Só então, já apreendida essas articulações da totalidade se pode expor seus segredos, para além das formas que emergem das abstrações de suas partes, em seu funcionamento e movimento contraditório.

Ou seja, a exposição em Marx, parte da aparência dos conceitos abstratos, particulares, rumo ao concreto histórico. Seu método de exposição em $O$ Capital, vai

[...] do abstrato ao concreto, da aparência à essência. Assim, o conceito de capital é desenvolvido pelo movimento negativo da obra, a partir de suas formas mais simples e aparentes, o movimento negativo de superação dialética avança para as formas mais complexas e concretas do capital. (Prado, 2009, p. 137).

Desta forma,

Marx inicia a crítica da sociedade burguesa e a exposição de seus conceitos e momentos fundamentais, tomando como ponto de partida as representações mais sensíveis e grosseiras que os agentes da produção, tanto operários quanto capitalistas, possuem sobre o próprio capitalismo. Toma como ponto de partida a opinião que ambos formam sobre a riqueza da sociedade burguesa e desta, escolhe a mercadoria singular para análise e crítica. Toma como ponto de partida, portanto, a própria temporalidade presente, imediata, cotidiana, destes agentes. Toma como ponto de partida em primeiro lugar, as representações mais sensíveis presentes na consciência mais imediata das duas classes fundamentais da sociedade burguesa e, simultaneamente, toma como ponto de partida histórico-temporal o tempo presente destes agentes. 
Um tempo lógico ainda não-conceitual, mas, sim, empírico, sensível, opinativo, intuitivo e um tempo histórico a-temporal, o presente imediato sem história naturalizado e obscurecido pelo cotidiano. (Antunes, 2005, p.38).

Parte então do abstrato e - aparentemente ahistórico - da riqueza e da forma-mercadoria até o último capítulo do livro I, o XXIV, sobre a acumulação primitiva do capital, quando já se mostrou que a aparente riqueza ahistórica é fundada sobre a exploração, que se esconde sob a forma-mercadoria e seu fetichismo, e culmina deitando por terra o último pressuposto, ao "demonstrar como o antagonismo entre a classe burguesa e proletária se fundou historicamente" (Prado, 2009, p.140). Ou seja,

A violência da luta de classes é o fim do primeiro livro de $O$ capital, fim que, na verdade, é princípio (Grund, arché), princípio pressuposto no modo de exposição desde o começo. Mas este princípio está pressuposto no modo de exposição não porque seja um princípio a priori, ele está lá no começo enquanto pressuposto, mas só na medida em que ele já está lá objetivamente e historicamente posto enquanto princípio do modo de produção capitalista. O que fez exatamente o desenvolvimento dialético do modo de exposição foi demonstrar qual é o princípio histórico que está posto sob as contradições do modo de produção capitalista. Mas, para justamente não cair no dogmatismo do entendimento, primeiramente, colocou o princípio como pressuposto para através do desenvolvimento realizar a sua ex-posição. No entanto, ao avançar do começo para o princípio (e isto foi sendo feito a cada desenvolvimento lógico que ganhava determinações 
históricas), as contradições se desenvolviam e as categorias da Economia Política burguesa e da economia burguesa eram negadas: a esfera da circulação (paraíso das ilusões) - a produção de maisvalia absoluta e relativa (manifestação da luta de classes) -, reprodução simples, acumulação de capital (transmutação das leis de propriedade e quebra definitiva da troca de equivalentes), acumulação primitiva (separação violenta dos produtores dos meios de produção, violência da luta de classes como princípio do capitalismo, violência como fim e novo princípio, negação da negação (socialismo).

Quando finalmente o princípio pressuposto (a violência da luta de classes) foi posto no seu começo (antes de toda riqueza capitalista, antes de toda mercadoria e da esfera do mercado), o modo de produção como um todo se nega e é necessário deduzir um novo princípio a partir desse princípio que se transformou em começo. O princípio que se negou como princípio, que se transformou em começo, é negado, e da negação da negação se caminha de maneira programática para um novo princípio, isto é, um novo modo de produção. Marx termina o capítulo XXIV dizendo: "Lá tratou-se da expropriação da massa do povo por poucos usurpadores, aqui trata-se da expropriação de poucos usurpadores pela massa do povo".

Este percurso, dialogando agora com o que tratamos mais acima, é uma corrida em direção à memória, à reconstrução da mesma de um ponto de vista popular e de suas lutas, e assim é também um retorno à história do poder, de suas violências originárias, desconstruindo o discurso ideológico, preenchendo as 
lacunas com o peso do sofrimento/conhecimento do passado e desvelando as incongruências do presente, desfazendo assim esse castelo de cartas, que um dia pareceu sólido como a Torre da Bastilha ou o Palácio de Inverno do Czar. Mais importante, ao desvelar a origem histórica da opressão, recoloca a possibilidade de superação histórica. Afinal, tudo que nasce não só pode, como um dia, deve morrer.

É preciso ainda acrescentar duas particularidades na passagem da exposição dialética dos escritos marxistas para uma exposição dialética em uma museologia marxista.

Primeiro, é que por mais que nesses escritos encontre-se uma perspectiva dialógica, pelo seu intuito e meio, ela é mitigada, pois mediada pela distância entre o escritor e o leitor. Já na exposição dialética museológica, ela é central. De certa forma, isto resgata elementos dos primórdios do método dialético na Antiguidade, que podem ser encontradas nesta perspectiva dialógica na filosofia socrática e nos textos platônicos. Em Platão, encontra-se

a dialéctica, praticada no e pelo diálogo da convivência, visa o apuramento da convivência, visa o apuramento de uma inteligibilidade genérica para o real e, muito em particular, para o real do mundo humano, ao jeito socrático de uma demanda de

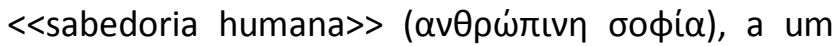
tempo, própria do homem e atinente às coisas humanas (Barata-Moura, 2012, p.41).

Guardadas as distâncias políticas e históricas que separam Platão de Marx e Engels, este método dialógico está condizente com a perspectiva do materialismo dialético, com o marxismo, e não casualmente, com o próprio método Paulo Freire naquele inspirado.

Em segundo lugar, claro que em uma exposição dialética que se processa não pelo discurso escrito, mas pelo processo 
dialógico, por outras mediações, como imagens, os objetos museológicos expostos, que servem de motor para o debate, podem não ser abstratos neste sentido, mas o debate a partir desses elementos concretos será mediado por um ponto de partida abstrato, da aparência, pois a ciência, como a consciência, avança em sucessivas aproximações da viagem do concreto ao abstrato e do abstrato ao concreto. Por exemplo, na exposição que será descrita a seguir, os objetos expostos eram fotos de ativistas que foram perseguidos por defenderem direitos humanos prometidos pela própria idéia de justiça burguesa como o suposto direito à igualdade entre todos os seres, independente de raça, credo, orientação sexual, origem nacional ou classe social. Esta é a promessa do liberalismo, ainda que apenas de uma igualdade formal, legal, nunca material que se trate e de que a expansão dos direitos abarcados nessa perspectiva terem sido produtos da própria história da luta de classes, que os ampliou para muito além do desejado inicialmente pela burguesia.

Nessa exposição estão casos concretos de violações desse princípio de justiça e dessa promessa ideológica do capitalismo. Há, no entanto, um conceito abstrato que de facto inicia, pois media a experiência com os casos concretos: este discurso da Justiça supostamente igualitária no capitalismo e a possibilidade da realização dos direitos humanos no sistema capitalista. Este é um elemento ideológico presente nas consciências das massas, que se apresenta, por exemplo, na crença das bases sindicais no recurso à Justiça para dirimir "de forma justa" os conflitos laborais - e aqui se apresenta o elemento de confusão que a forma-Judiciário carrega, de que este poder estaria ligado à resolução do justo, e não ao domínio de classe.

A partir do diálogo, foi possível - e esta era a intenção levar o debate em torno aos casos particulares e este elemento ideológico inicial, demonstrando as contradições, apontando para a totalidade sistêmica, de como a farsa desse princípio ideológico 
se apresenta de forma universal, ainda que em expressões particulares. Foi-se assim das discussões particularizadas para a geral, demonstrando pelo debate que se muitos ali eram negros e outros eram brancos; se muitos eram mulheres e outros homens; se alguns eram heterossexuais e outros homossexuais e mesmo transexuais; se uns eram europeus e estadunidenses, outros eram latino-americanos, africanos ou árabes; se alguns eram ativistas comuns, outros foram presidentes ou líderes partidários; se alguns utilizaram meios pacíficos, outros a resistência armada; todos, independentemente de lutarem contra o machismo, o racismo, a homofobia, o fascismo, ou em defesa libertação nacional ou colonial, e também independente do método que utilizaram, seja por via eleitoral, insurreição, luta armada ou desobediência civil, todos viram a Justiça e o Sistema Legal negarem seus direitos e, por isso, sofreram perseguições, seja por métodos legais, seja por métodos extra ou ilegais, e foram reprimidos e, em muitos casos, mortos. A partir desse motor era possível avançar para o aprofundamento do caráter real do sistema legal, bem como dos motivos por detrás disto, e a ligação do Judiciário com o poder de classe, e como isto se expressava na negação da concretização dos direitos humanos para os diversos segmentos populares.

Porém, não nos adiantemos, e passemos a explicar como foi o processo de gestação e realização dessa exposição.

A exposição Linha de Frente

A exposição Linha de Frente: Mulheres e Homens em luta pelos Direitos Humanos surgiu no dia 02 de abril de 2018 na Casa do Alentejo, durante uma reunião do Coletivo Andorinha, grupo

Formado em grande parte por brasileiros estudantes, professores e pesquisadores das mais diversas áreas, assim como por trabalhadores brasileiros e portugueses simpatizantes à causa, o Coletivo Andorinha tem como motor primeiro tentar compreender a situação política do Brasil atual e 
discutir contra narrativas não veiculadas pela mídia tradicional. [...] O grupo trabalha de forma horizontal, onde as decisões são tomadas por aqueles que podem estar presentes e que podem doar seu tempo no momento. Sem a necessidade de hierarquização de cargos ou vontades, as ações acontecem ou quando notícias surgem por internet $\mathrm{e}$ são ocultadas pela mídia tradicional, tanto brasileira quanto portuguesa, ou quando convocados por eventos portugueses. As ações são coordenada a partir do interesse, do desejo de alguns dos integrantes, seja de todos, seja de poucos. O Coletivo Andorinha se coloca como um espaço de reflexão e pensamento, que se traduz em seus manifestos, materiais gráficos e discursos, mas que se afirma nas ações de rua e nas produções de fotos e vídeos destas, em caráter de denúncia. Na tentativa de contar a história pelo ponto de vista não controlado pelo mercado, mas também de expurgar, e de canalizar, os sentimentos de frustração, decepção, raiva e medo presentes atualmente em um número expressivo da comunidade brasileira fora de seu país de origem. (Souza, 2017, p 163 e 166).

A proposta era organizar um evento político-cultural com a presença de coletivos e movimentos democráticos, negro, LGBQTTT $^{18}$ e feminista, em homenagem à vereadora brasileira Marielle $\mathrm{Franco}^{19}$, na ocasião em que se completaria um mês de sua brutal execução, até então sem solução por parte da polícia.

\footnotetext{
${ }^{18}$ LGBQTTT é a sigla de Lésbicas, Gays, Bissexuais, Queers, Travestis, Transexuais e Transgêneros, que consistem em diferentes tipos de orientações sexuais.

19 "Marielle Franco é mulher, negra, mãe e cria da favela da Maré. Socióloga com mestrado em Administração Pública. Foi eleita Vereadora da Câmara do Rio
} 
O objetivo central do evento era, através da arte, "ampliar a representatividade" das causas defendidas por Marielle Franco (Flor, 2018) e, para tanto, várias foram as atividades programadas: debate sobre a presença feminina na capoeira com o grupo Capoeira Angola Irmãos Guerreiros; leitura de poesias "A Herança do Ouvido" com Rádio AfroLis + Djidiu; performance artística de Thaís Zaki; apresentação dos blocos carnavalescos Colombina Clandestina e Baque do Tejo + Slam; performance da Drag Queen e ativista LGBQTTT Paula Lovely; concerto "Protesto em Canção" por Isabella Bretz e Francisco Medina.

Diante deste quadro, pensamos ser esta uma boa ocasião para darmos o pontapé inicial no recém criado Laboratório Experimental de Museografia Social do Departamento de Museologia da Universidade Lusófona e, assim sendo, nos oferecemos para pensar uma exposição adequada a temática do evento e que também estivesse de acordo com as pautas do Coletivo Andorinha.

Esta exposição ocorre nos marcos do que chamamos de Museologia da Urgência. Pois, carrega em si dois sentidos da urgência. O de uma museologia feita temporalmente com urgência, com a necessidade de atender demandas surgidas na dinâmica da vida, por isso sem necessariamente os prazos de um fazer Museologia Alienada, pois é esta alienada das demandas prementes e alienada das questões materiais, pois é abastada. É

de Janeiro pelo PSOL, com 46.502 votos. Foi também Presidente da Comissão da Mulher da Câmara. [...] Trabalhou em organizações da sociedade civil como a Brasil Foundation e o Centro de Ações Solidárias da Maré (Ceasm). Coordenou a Comissão de Defesa dos Direitos Humanos e Cidadania da Assembleia Legislativa do Rio de Janeiro (Alerj), ao lado de Marcelo Freixo. Iniciou sua militância em direitos humanos após ingressar no pré-vestibular comunitário e perder uma amiga, vítima de bala perdida, num tiroteio entre policiais e traficantes no Complexo da Maré. Aos 19 anos, se tornou mãe de uma menina. Isso a ajudou a se constituir como lutadora pelos direitos das mulheres e debater esse tema nas favelas. Mari dizia que ocupar a política é fundamental para reduzir as desigualdades que nos cercam." (\#MarielleVive, 2018) 
também uma Museologia da Urgência, pois é também uma Museologia Militante, que precisa atender com urgência as demandas que são urgentes para os setores populares, é uma forma de militância política mediada pela museologia, bem como uma forma de museologia ao serviço da militância política. Neste caso, não apenas pelo tempo escasso, mas pelo caráter central e mesmo vital das respostas, que são muitas vezes negadas, relegadas ao segundo plano ou mesmo contrariadas pelos poderes das classes dominantes. É Museologia da Urgência, pois reflete a vida, a sociedade, por ser assim um desdobramento da Museologia Social.

No metrô, voltando para casa, ainda discutíamos sobre a temática da exposição, o que poderia ser feito em tão pouco tempo e recurso, uma exposição a ser montada na rua e que ainda não tinha nem ao menos o tema definido.

Começamos então por aí, o tema. Já que a proposta central do evento era através da arte, "ampliar a representatividade" das causas defendidas por Marielle Franco (Flor, 2018), pensamos em apresentar ao público outros militantes de todo o mundo que, assim como Marielle Franco, foram ou ainda são perseguidos na luta pela dignidade humana. E assim vários nomes surgiram, primeiramente oriundos das pautas do próprio Coletivo Andorinha, e depois, ao compartilharmos a idéia com os demais, outros nomes foram se integrando a proposta de exposição e assim totalizamos uma primeira listagem com vinte e oito nomes.

Estes nomes não surgiram aleatoriamente, como já foi dito, os indivíduos retratados são pessoas que, ao longo de sua vida ou em um momento específico, lutaram em prol dos direitos humanos, proclamados pela Assembléia Geral das Nações Unidas, no dia 10 de dezembro de 1948, que em 2018 completa setenta anos.

É importante que esteja clara a intenção desta proposta expositiva. Ao contrário do que possa parecer, este projeto não tem como foco fazer uma homenagem a estes indivíduos 
retratados, nosso objetivo é usar suas histórias de vida e luta para criar um espaço de debate sobre estes temas. Ou seja, a exposição Linha de Frente tem como tema a luta pelos direitos humanos, o desvio do justo e a injustiça (legal e social) e usa como ferramenta para embasar o seu discurso expositivo as histórias de vida daqueles que lutaram e ainda lutam, das mais diversas maneiras, a favor da dignidade humana em todos os seus aspectos.

Ao contrário da Museologia Tradicional, que precisa dos grandes tesouros para compor as suas exposições, nossa proposta não está focada em ídolos (vivos ou mortos) ou até mesmo colocar suas lutas em uma vitrine para o deleite apreciativo. Buscamos construir uma proposta viva, que dê voz a estes indivíduos colocando suas lutas em pauta, em debate. Uma Museologia conectada com as demandas da vida, pois como já dizia Mário Chagas: uma museologia que não serve para a vida, não serve para nada. E, por isso, uma exposição dialética, que expõe as contradições, permitindo a abertura ao debate. Não só a contradição sistêmica, mas dos próprios indivíduos, que são contraditórios, bem como os movimentos e processos, que também em si são contraditórios, mas que também estabelecem relações dialéticas, portanto, contraditórias, com suas lideranças.

Infelizmente, o projeto não se concretizou como atividade do Laboratório Experimental de Museografia Social, pois parte da equipe do Laboratório não concordou com dois dos nomes elencados para a exposição: o ex-presidente do Brasil, Luiz Inácio Lula da Silva e o ex-presidente da Generalidade da Catalunha, Carles Puigdemont. Divergências estas graves, pois ambos representam pautas relevantes para o Coletivo Andorinha: a prisão arbitrária de Lula da Silva e o direito de livre escolha do povo catalão. Então, a realização da exposição ficou a cargo exclusivamente do Coletivo e o Laboratório passou a ter como sua diretriz primeira não atuar na curadoria de seus projetos. Ainda assim, a parceira com a Universidade Lusófona se manteve 
através do apoio pelo seu Departamento de Museologia, que fez a impressão de todo o material gráfico.

Mas, a exclusão dessas duas figuras contrariaria também outros aspectos da perspectiva que se quer construir de uma exposição dialética. Primeiro, excluiriam dois líderes importantes, de dois processos distintos e conhecidos, sob os quais podemos ter divergências e avaliações díspares - o que é saudável para o amadurecimento político e o debate - mas que sofrem repressões e violações de direitos humanos básicos (como ao julgamento justo e ao direito à autodeterminação). Isto teria duas conseqüências. Enfraqueceria a intenção de apontar a universalidade e as distintas formas de materialização da contradição entre o discurso legal e democrático liberal e a realidade do poder de classe que o viola.

Porém, mais do que isto: a intenção central de uma exposição dialética é apresentar todas as contradições que são suprimidas pelo discurso hegemônico burguês, forma de poder repressor. Ao retirar os dois, isso iria contra esta intenção, e iria no sentido do reforço do discurso ideológico burguês e seria mais uma forma de violência contra os movimentos populares, reforçando o poder repressivo. Ao retirar os dois não se estaria garantindo neutralidade discursiva, pois esta não existe. Ou se está do lado da repressão política e do domínio de classe, ou se está do lado da liberdade, do direito, da justiça e da superação do domínio de classe. Ao retirar se faz já um discurso, pelo silenciamento. Este é o discurso que o golpe de Estado de 2016 quer fazer não com o Lula, que apenas representa - e em muitos casos, mal representa - o movimento popular, o povo e a esquerda. Este é o discurso da Monarquia Espanhola, das viúvas do franquismo, do Partido Popular e do regime de 78. Colocá-los rompia com o discurso do silenciamento, e colocava a possibilidade da abertura para o diálogo, mesmo para o embate. É sempre melhor, em uma perspectiva de uma museologia marxista, expor a contradição e gerar o conflito, do que calar o 
conflito, um segundo nível de violência, que é para além da violência física, a violência da negação da própria existência.

A manutenção dos dois foi importante para o debate. No caso de Puigdemont o entendimento popular quase generalizado da violação do direito à autodeterminação dos povos levou à quase inexistência de críticas por parte do público, à exceção de uma senhora, curiosamenente basca, com uma perspectiva reacionária da sociedade, que questionou, mas possibilitou um debate interessante com o grupo que visitava a exposição naquele momento. Já a figura de Lula engendrou muito mais debate, devido a presença de muitos turistas brasileiros, que tanto debatiam os vícios do processo e criticavam o golpe de Estado em curso, como de setores que eivados do discurso ideológico midiático discordavam da presença dele em meio aos demais, seja de forma dialógica, seja de forma conflituosa, como ocorreu com o aparecimento de setores de extrema-direita brasileira que agiam com atitude violenta e provocadora. Mesmo isto foi positivo, tanto por alcançar com o objetivo teóricopolítico da exposição dialética de trazer à tona a luta de classes, como por demonstrar que se alcançou um objetivo formal, que é a ruptura com a rigidez comportamental que é imposta nos espaços expositivos tradicionais, tal como museus enquanto catedrais e espaços sagrados, criando um espaço que pode ser mais barulhento, menos regrado, mais confuso e conflituoso, mas por isso mais vivo, e que traz para si os conflitos sociais.

Mesmo não mais integrando as atividades do Laboratório, a exposição Linha de Frente: Mulheres e Homens em luta pelos Direitos Humanos seria realizada nos marcos daquilo que, ainda de forma experimental, pensamos ser uma Museografia Social, comprometida com as demandas da sociedade e que o discurso museográfico possa se converter em ferramenta política de forma acessível, sustentável (social, financeira e ecologicamente) via uma curadoria participativa e aberta. 
Expor é ou deveria ser, trabalhar contra a ignorância, especialmente contra a forma mais refractária da ignorância: a ideia pré - concebida, o preconceito, o estereótipo cultural. Expor é tomar e calcular o risco de desorientar - no sentido etimológico: (perder a orientação), perturbar a harmonia, o evidente, e o consenso, constitutivo do lugar comum (do banal). No entanto também é certo que uma exposição que procuraria deliberadamente escandalizar traria, por uma perversão inversa o mesmo resultado obscurantista que a luxúria pseudo - cultural. ... entre a demagogia e a provocação, trata-se de encontrar o itinerário subtil da comunicação visual. Apesar de uma via intermédia não ser muito estimulante: como dizia Gaston Bachelard, todos os caminhos levam a Roma menos os caminhos do compromisso. (Thévoz, 1984, p. 167).

A exposição em si (figura 1) era composta por vinte e oito fotografias, sendo treze militantes históricos já falecidos (imagens impressas em preto e branco) e quinze imagens de indivíduos que ainda hoje lutam e são, de formas distintas, perseguidos por seus ideais (imagens impressas a cores). Este recurso expográfico tinha uma intenção de promover a dúvida, como foi principalmente e bem sucedidamente desenvolvido com as crianças, em cima do porquê da diferença de cores. As crianças, por exemplo, foram apontando possibilidades, como serem fotos antigas e novas, por exemplo, até chegarem a conclusão de que uns estavam vivos e outros mortos. Para além de ser um estímulo intelectual, a intenção era demonstrar tanto o nível a que poderia chegar o desrespeito aos direitos humanos e as injustiças, ou seja, até à morte - ainda que alguns dos mortos tenham falecido por causas naturais -, bem como a continuidade da opressão e da injustiça, 
demonstrando que este não é um fenômeno apenas do presente, mas um fenômeno histórico e continuado. Também houve a preocupação, como já referido, de se garantir a representação de variadas formas de lutas e violações de direitos, bem como espacial, com representações de vários países e regiões, demonstrando que não há um exclusivismo geográfico - afinal, o capitalismo é mundial.

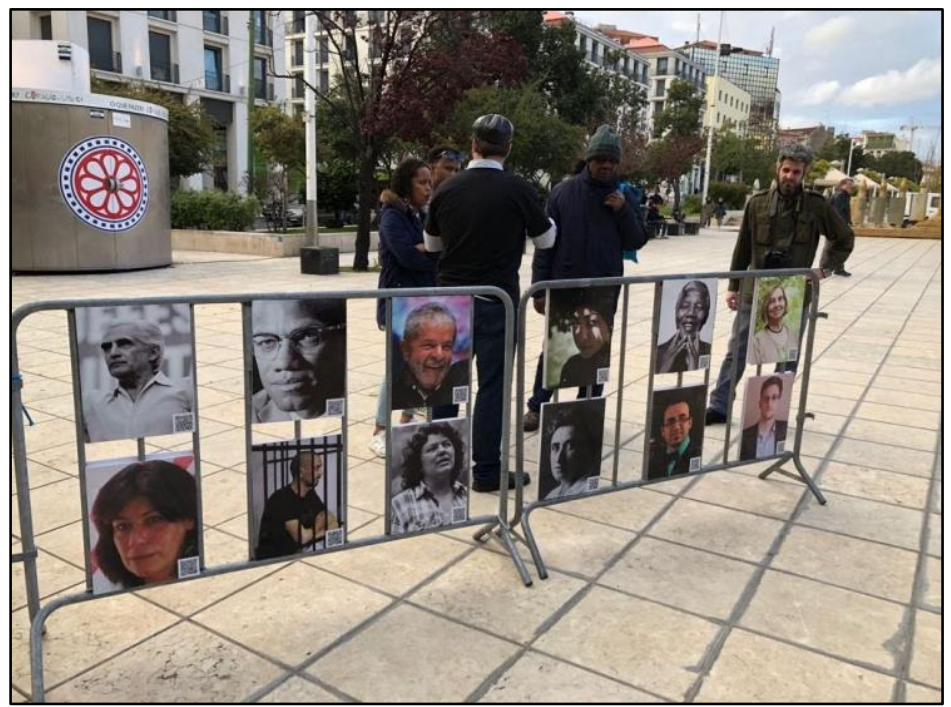

Figura 1 - Foto: Coletivo Andorinha

A exposição foi montada em plena praça Martim Moniz e tivemos que usar de criatividade na fixação do material gráfico. Ficou patente assim, durante a montagem, as dificuldades materiais e as necessidades de adaptação criativa ao espaço, próprias de uma Museologia da Urgência e de uma Museologia Militante que são, ao contrário da Museologia Alienada, normalmente realizados sob pressão e sob condições nem sempre ótimas e apropriadas. Nestes sentidos, do caráter adaptativo da montagem, com a utilização dos recursos 
disponíveis; de ser instrumento para golpear o poder em lugares menos esperados; de não guardar território - afinal, a exposição está um dia em uma praça, noutro pode estar em um sindicato, em outro num centro de lazer, etc; da necessidade de uma habilidade prática que supere as adversidades; da ligação da vanguarda com setores mais amplos - como, por exemplo, o apoio dos recursos de outros militantes não diretamente ligados ao processo; com a necessidade de um planejamento prévio, ainda que contando sempre com a contingência; e, por fim, com o compromisso não com a forma perfeita, mas com a exposição necessária, a montagem expressou uma verdadeira Museologia de Guerrilha. Por exemplo, como ocorreu quando na montagem utilizamos anteparos que estavam deixados na própria praça, subvertendo-os em seu uso; a necessidade de adaptar a exposição a essa condição, inclusive para solucionar o problema da grande ventania existente, forçando a retirada de quatro fotografias para garantir sua afixação correta - feita por isso não com o material que veio da gráfica, mas com fitas adesivas - e utilizando uma fotografia como anteparo de outra fotografia, etc.

Outro aspecto relevante é que cada fotografia está acompanhada por um QR Code que, através do uso de um smartphone ou tablet, acessa um website onde o público irá encontrar mais informações sobre quem estava retratado. A idéia central do uso de QR Codes é instigar do público, despertando a curiosidade a respeito da identidade dos indivíduos representados nas fotografias. Contudo, não tínhamos qualquer tipo de legenda ou título nas imagens, apenas o QR Code, uma ferramenta que, ao contrário de textos expositivos tradicionais, oferece uma infinidade de possibilidades em termos de quantidade e também de qualidade das informações a serem disponibilizadas.

O código denominado QR Code (sigla do inglês Quick Response, reposta rápida em português) surgiu em 1994 no Japão para catalogar peças da indústria automobilística. Sua 
versatilidade logo o converteu em uma ferramenta útil para os mais diversos fins, sendo hoje amplamente utilizado em todo o mundo.

Mas o que é, afinal, um QR Code? É um código de barras em 2D que pode ser escaneado pela maioria dos aparelhos celulares que têm câmera fotográfica. Esse código, após a decodificação, passa a ser um trecho de texto, um link e/ou um link que irá redirecionar o acesso ao conteúdo publicado em algum site. [...] O procedimento de leitura de um QR Code é simples. Execute o aplicativo instalado no seu celular, posicione a câmera digital de maneira que o código seja escaneado. Em instantes, o programa irá exibir o conteúdo decodificado ou irá redirecioná-lo para o site do link que estava no código. (Prass, 2011).

Tal como uma legenda, o QR Code é uma imagem estática, porém sua capacidade de armazenamento de informações é gigantesca. Por ser um código que direciona o público à Internet, - QR Code torna possível o acesso a toda a informação apresentada no seu destino. Sendo assim, cada QR Code da exposição Linha de Frente direciona os visitantes a um website onde se pode encontrar um texto informativo sobre o indivíduo retratado, vídeos e links com mais informações, além de possibilidade de acessar as páginas dos demais retratados na exposição.

Outro aspecto interessante é que, por se tratar de um conteúdo online, podemos corrigir e até mesmo atualizar os dados sem que isso altere o material gráfico produzido. E aí temos outro diferencial na proposta desta exposição: o público pode enviar sugestões de outros nomes para integrar a coleção. Mesmo com a exposição desmontada, desejamos manter o website online, sendo constantemente atualizado e ampliado 
com a inclusão de mais e mais nomes, pois enquanto houver pessoas lutando pelos direitos humanos, vamos ter material para a exposição Linha de Frente: Mulheres e Homens em luta pelos Direitos Humanos.

Trabalhamos com o conceito de Curadoria Aberta. Em nossa perspectiva, a exposição dialética, como uma Museologia Marxista, tem que ser um processo aberto. Por várias razões. Em primeiro lugar, pois isto é um processo de democratização real, pois quando se fala de democratização dos museus, em geral, "mais não é que o alargamento do consumo museológico a extractos sociais até agora afastados desse consumo" (Moutinho, 1989, p.92). Neste sentido, também colaboramos com a democratização, pelo lado do consumo, levando a exposição para a rua e para internet, colocando à disposição de todos, do setor popular, e também territorialmente, ainda que no momento só acessível para os falantes de português. Mas, nossa preocupação, e isto se expressou com a curadoria aberta, é com a democratização da produção expográfica. Um elemento neste sentido é a curadoria ter sido assumida, como toda a exposição, não como a produção de dois ou três, ainda que por limites de tempo e meios ela tenha sido realizada por um grupo menor que o conjunto integral do coletivo, mas ainda assim, por um grupo. A exposição é propriedade do Coletivo Andorinha, e "propriedade real e poder de decisão são as duas faces de uma mesma moeda" (Moutinho, 1989, p.89). Contudo, pela urgência da realização da exposição, a socialização dos meios técnicos de produção expográfica não ocorreu, o que é algo a ser ajustado. Há que se equilibrar a Museologia da Urgência com a socialização necessária em uma perspectiva museológica marxista.

O próprio processo de curadoria ser apresentado como coletivo e aberto carrega em si a perspectiva participativa e de movimento que uma Museologia Marxista e uma exposição dialética exigem. Também, torna a exposição em algo em si dialético, pois vivo e em permanente movimentação e 
transformação, indo no sentido apontado recorrentemente por Mário Chagas de um museu vivo, para a vida. Por fim, também afirma o caráter dialético, pois ao retirar o protagonismo de poucos e envolver um coletivo, seja na ação direta, como no pedido, ele trouxe dois efeitos que consideramos positivos: partiu-se de um horizonte de demandas já concretas do coletivo e articulado com suas lutas; e possibilitou na própria investigação necessária para a preparação da etapa expositiva dialética, da emergência de contradições que clarificaram posições e aprofundaram os debates, preparando os pontos iniciais para o debate geral com o público.

A ação educativa complementar estava conectada com a proposta de Curadoria Aberta. As crianças que participaram da oficina artística, proposta pela psicóloga, educadora e também integrante do Coletivo Andorinha, Gisele Navarro Fernandes, além de conhecer a história de cada um dos retratados de forma lúdica e apropriada para sua faixa etária, puderam demonstrar sua solidariedade através de intervenções artísticas na exposição in situ: fitas brancas com mensagens foram fixadas junto às fotografias (figura 2).

Em relação às crianças, dois momentos foram paradigmáticos do avanço de consciência pretendido, da demonstração da injustiça do sistema capitalista a partir da injustiça do sistema legal. Ao final, ao serem questionadas, a identificação maior das crianças ocorreu com Lula da Silva. Contudo, o mais importante foi o motivo da escolha, que não foi produzida por nenhuma indução na condução, mas pela ponte construída entre o caso dele e a percepção da injustiça da prisão. O choque das crianças se expressou na fala de uma delas, que correu com expressão consternada para a mãe dizendo: "Mãe, você sabia que o Lula foi preso sem provas!?". Isto expressava a ponte entre as experiências diretas da criança, do aborrecimento por ser castigado por algo que não foi feito, e este senso de justiça próprio dos miúdos e o "castigo injusto" de Lula. 


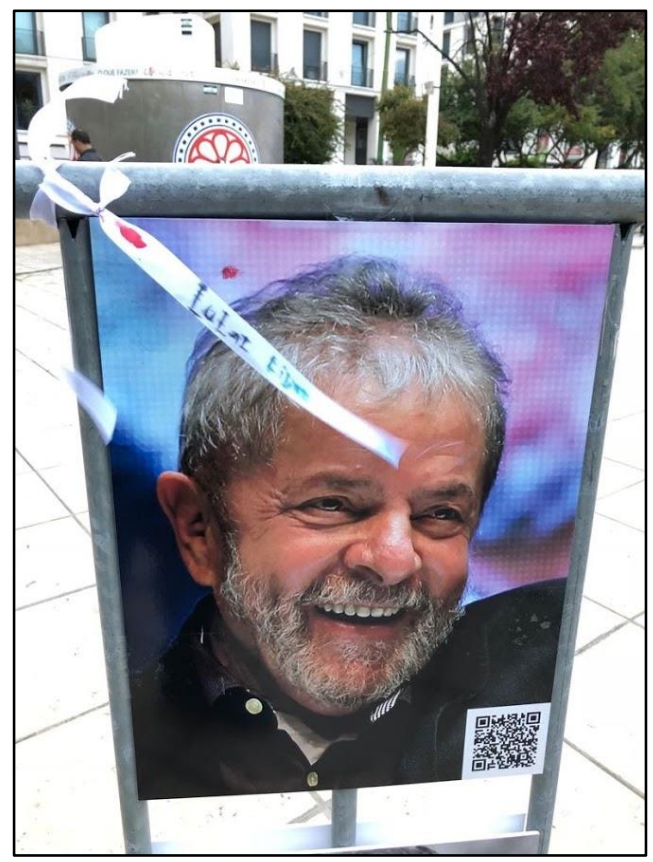

Figura 2 - Foto: Coletivo Andorinha.

Outro momento importante dessa experiência foi em relação ao ucraniano Denis Shatunov. Ele foi apontado já na perspectiva de Curadoria Aberta, indicado pela organização revolucionária socialista desse país, Borotba (Luta), que como todas as organizações de esquerda tiveram ou forçadas a ir para a clandestinidade após o golpe de Estado de 2014, que levou ao governo uma frente neoliberal-fascista, e colocou nas ruas como forças dominantes - e com conivência de membros do Estado das milícias fascistas, que aterrorizam a população nas ruas na Ucrânia e conformam batalhões de voluntários contra o movimento de resistência antifascista das Repúblicas Populares de Donetsk e Lugansk. Shatunov está preso sem motivos à exceção de ser um militante de esquerda, e por ter expressado 
indignação pela absolvição do neonazista e assassino confesso de seu melhor amigo durante o chamado Massacre de Odessa em 2 de maio de 2014 , perpetrado pelas hordas fascistas. O principal elemento da experiência foi a desconstrução da concepção de justiça do sistema prisional. A foto de Denis é a única que apresenta o retratado atrás das grades. Na conversa com as crianças, ao se perguntar o porquê de o mesmo estar naquela situação, a primeira reação foi, seguindo os estereótipos ideológicos que já tinham absorvido pela vida, de que ele seria "um homem mau". Ao se apresentar a história dele, a revolta se apresentou nas crianças, mas principalmente, se percebeu que nem sempre quem está atrás das grades é um criminoso ou um "homem mau", e nem sempre quem está livre é "bom", como no caso do nazista; de que a inocência e a culpa não é o único critério para a aplicação da lei; de que o poder de classe subverte no Judiciário o critério de justiça e de direito, logo não é neutra e, por isso, é preciso ir para além das aparências nas análises, e perceber o contexto e as contradições existentes.

A montagem na praça Martim Moniz nos proporcionou a possibilidade de testarmos o conceito de Curadoria Aberta por diversas vezes. Destacamos a participação de alguns moçambicanos, entre eles uma das dirigentes de uma associação de moçambicanos em Itália que, ao verem a fotografia de Samora Machel $^{20}$, logo indagaram aos mediadores a respeito desta escolha, perguntando como funcionava a seleção e, ao perceberem que poderiam participar, sugeriram o nome a ser incluído de Eduardo Mondlane ${ }^{21}$. Sobre a figura de Samora Machel ocorreram de facto as maiores polêmicas, seja com críticas, sempre educadas e em jeito de conversa, seja com o elogio pela escolha, tanto por moçambicanos como por

\footnotetext{
${ }^{20}$ Um dos líderes da luta pela independência moçambicana e que se tornou o primeiro presidente de seu país.

${ }^{21}$ Um dos fundadores e primeiro presidente da Frente de Libertação de Moçambique (FRELIMO).
} 
portugueses, pois a sua representação era importante no debate de desconstrução de todo o discurso - de cunho racista e colonialista - que se deu em Portugal após a independência de Moçambique, apresentando-o como parvo e o desqualificando.

O trabalho de mediação (figura 3) foi muito importante para a compreensão rápida da proposta da exposição. Por mais que os QR Codes já apresentassem ao público todos os detalhes do projeto, os mediadores atuaram como facilitadores deste processo e também como os dinamizadores do diálogo expositivo.

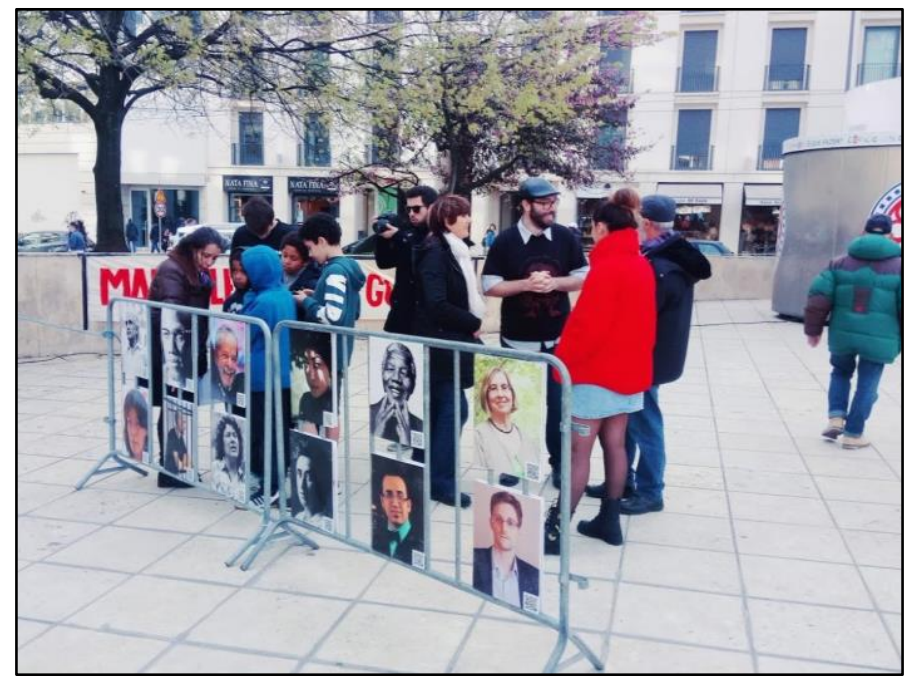

Figura 3 - Foto: Coletivo Andorinha

Visando ampliar o debate, a exposição Linha de Frente: Mulheres e Homens em luta pelos Direitos Humanos está disponível para o download. Quem tiver interesse em montá-la, basta solicitar o envio do material gráfico por e-mail para impressão, sem custos ou implicações em direitos autorais. Lembrando que todas as fotografias estão acompanhadas dos seus respectivos QR Codes, o que implica também ao acesso a 
todo o conteúdo disponibilizado no website da exposição. Isto se apóia nos aspectos de socialização engendrados pelas forças produtivas - ainda que estas convivam com tendências monopolizadoras, centralizadores e concentradoras das relações de produção capitalista. Permite-se, nesta era de reprodutibilidade técnica ${ }^{22}$, a realização da proposta de Mário de Andrade de um 'museu de reproduções' (Abreu, 2015, p.22).

\section{Conclusão}

À guisa de conclusão, ainda que não significando um ponto final, mas sinalizando para a continuação e aprofundamento das elaborações e experiências aqui descritas, podemos extrair alguns apontamentos prévios. O principal é que, apesar de ser uma primeira aplicação de nossa proposição de exposição dialética, a Linha de Frente alcançou os resultados pretendidos. Como uma primeira aproximação prática dessa elaboração teórica, não alcançou todos os limites possíveis, mas realizou seu principal objetivo, o de avançar a consciência dos indivíduos, particularmente sendo bem-sucedido com as crianças. Comprovou-se o caráter correto de não tergiversar com os embates, expondo as contradições e superando o discurso de silenciamento realizado pelo poder.

Também, ainda que mediado, permitiu a socialização da prática museológica de forma popular, mesmo que não em sua plenitude devido ao caráter urgente da exposição. É preciso encontrar um equilíbrio, que talvez só a atividade permanente possa dar, entre a Curadoria Aberta e a socialização das práticas com a Museologia da Urgência. A chave nos parece seja a constância e ligação orgânica com a militância, ou seja, o conceito e prática mediadora da Museologia Militante.

\footnotetext{
${ }^{22}$ Cf. sobre o tema no âmbito da arte e numa perspectiva marxista, Walter Benjamin (s.d.).
} 
Como resultado teórico inicial, se demonstrou a necessidade de elaboração de outros conceitos que emergiram com a prática. Ou seja, a práxis da exposição dialética levou à construção de outros conceitos associados, de Museologia da Urgência (e por contradição, a de Museologia Alienada), Museologia Militante, e Museologia de Guerrilha, que exigirão um tratamento aprofundado em futuros artigos.

Por fim, a nossa opinião de que a Sociomuseologia ganharia com a explicitação das influências marxistas, para nós já se comprovou enquanto instrumento fecundo para a elaboração de novas práticas e novos conceitos teóricos associados, que se desdobraram do conceito de exposição dialética, derivado da interpenetração dialógica das discussões de poder da Sociomuseologia e dos conceitos marxistas. Cabe agora testar nossa outra hipótese, de que o marxismo pode ajudar a rever conceitos já consolidados e superar obstáculos epistemológicos e teóricos que possam existir na Sociomuseologia. Porém, isto também ficará para outro momento. Por hoje, ao que nos cabe, acta est fabula ${ }^{23}$.

\section{Referências Bibliográficas}

Abreu, Regina. (2015). Dois Mários e um sem-número de museus polifônicos. In: Mário de Souza Chagas. Há uma gota de sangue em cada museu: a ótica museológica de Mário de Andrade. 2a Ed. Revista e atualizada. Chapecó, SC: Argos.

Anderson, Perry. (1992). O fim da história - de Hegel a Fukuyama. Rio de Janeiro: Jorge Zahar Editor.

Antunes, Jadir. (2005). Da possibilidade à realidade: o desenvolvimento dialético das crises em $O$ Capital de Marx. Tese de Doutoramento em Filosofia, Unicamp/IFCH, Campinas.

Arcary, V. (s.d). Um processo revolucionário mundial em forma de ondas sincronizadas, as cinco vagas revolucionárias do século $X X$. Recuperado em: http://www.cefetsp.br/.

\footnotetext{
${ }^{23}$ Expressão romana que era utilizada no encerramento dos espetáculos para indicar seu fim.
} 
Arcary, Valério. (2006). O encontro da revolução com a história: socialismo como projeto na tradição marxista. São Paulo: Instituto José Luís e Rosa Sundermann; Xamã.

Barata-Moura, José. (2012). Totalidade e contradição: acerca da dialéctica. $2^{a}$ ed. Aumentada e revista. Lisboa: Editorial Avante!

Benjamin, Walter. (s.d. [1955]). A obra de arte na era de sua reprodutibilidade técnica. Recuperado em: https://edisciplinas.usp.br/

Cândido, Manuelina Maria Duarte. (2009). CAPÍTULO 1 - VAGUES - A

ANTOLOGIA DA NOVA MUSEOLOGIA. Cadernos de Sociomuseologia, [S.I.], v. 20, n. 20, june 209 Recuperado em:

http://revistas.ulusofona.pt/index.php/cadernosociomuseologia/index .

Chagas, Mário Souza. (2012). Museus, memórias e movimentos sociais.

Cadernos de Sociomuseologia, [S.I.], n. 41, feb. 2012. ISSN 1646-3714.

Recuperado em:

http://revistas.ulusofona.pt/index.php/cadernosociomuseologia/

; M. Gouveia, I. (2014). Museologia social: reflexões e práticas (à guisa de apresentação. In: Cadernos do CEOM, Ano 27, n. 41. Museologia social, p. 9 22.

Engels, Friedrich. (1877). Anti-Dühring. Recuperado em:

https://www.marxists.org/.

Flor, Aline. (2018). Um mês depois, Lisboa não deixa esquecer Marielle Franco. Recuperado em https://www.publico.pt .

Fukuyama, Francis. (1992). O fim da história e o último homem. Rio de Janeiro: Rocco.

Lénine, V.I. (1984). Duas Utopias. In: Obras Escolhidas em seis tomos, Edições "Avante!". Recuperado em: https://www.marxists.org/.

Lénine, V.I. (2000). As Três Fontes e as Três partes Constitutivas do Marxismo. Recuperado em: https://www.marxists.org/.

Lincoln, Abraham. (s.d.). DISCURSO DE ABRAHAM LINCOLN. Recuperado em: http://www.arqnet.pt/.

Lukács, Georg. (2003). História e consciência de classe: estudos sobre a dialética marxista. São Paulo: Martins Fontes.

Marx, Karl. (1990). Posfácio à segunda edição. In: . O Capital: crítica da Economia Política. Recuperado em: https://www.marxists.org/ .

Marx, Karl. (2003). O 18 de Brumário de Louis Bonaparte. Recuperado em: https://www.marxists.org/.

Marx, Karl. (2006). Carta a Joseph Weydemeyer. Recuperado em: https://www.marxists.org/.

Marx, Karl. (2011). Grundrisse: manuscritos econômicos de 1857-1858: esboços de crítica da economia política. São Paulo: Boitempo.

Marx, Karl; Engels, Friedrich. (1997). Manifesto do Partido Comunista. Tradução José Barata-Moura. Lisboa: Editorial Avante!. 
Miguel, Luis Felipe. (2002). A democracia domesticada: bases antidemocráticas do pensamento democrático contemporâneo. Dados, 45(3), 483-511. Recuperado em: https://dx.doi.org/10.1590/S0011-52582002000300006 Moutinho, Mário. (1989) Museus e Sociedade. Monte Redondo (Portugal): Museu Etnológico, Col. Cadernos do Patrimônio, no5.

Moutinho, Mário. (2017). MINOM: 30 anos de Museologia em favor dos Direitos Humanos. Cadernos de Sociomuseologia, [S.I.], v. 54, n. 10, july 2017. Recuperado em: http://revistas.ulusofona.pt/index.php/cadernosociomuseologia/ .

Prado, Carlos. (2009). A dialética expositiva de O Capital de Karl Marx. Revista Espaço Acadêmico, 100, setembro 2009. Recuperado em:

http://periodicos.uem.br/.

Prass, Ronaldo. (2011). Entenda o que são os 'QR Codes', códigos lidos pelos celulares. Recuperado http://g1.globo.com/tecnologia .

Primo, Judite. (2014). O SOCIAL COMO OBJECTO DA MUSEOLOGIA. Cadernos de Sociomuseologia, [S.I.], n. 3, june 2014. ISSN 1646-3714. Recuperado em: http://revistas.ulusofona.pt/index.php/cadernosociomuseologia/ .

Salvat. (1979). Os Museus no Mundo. Biblioteca Salvat de Grandes Temas. (v.26.) Rio de Janeiro: Salvat Editora do Brasil.

Saviani, D. (2008). História das idéias pedagógicas no Brasil. Campinas: Autores Associados.

Souza, Samara Azevedo de. (2017). Coletivo Andorinha: um ano de existência, de resistência, de política, de arte, de educação. Revista Matéria-Prima.

Soto, Moana. (2017). "E a Palavra se fez carne": A influência de Paulo Freire na Nova Museologia. Projeto de Tese de Doutoramento em Museologia, Universidade Lusófona de Humanidades e Tecnologias, Lisboa.

Thévoz, Michel (1984). Esthétique et/ou anesthésie museographique, Objets Prétextes, Objects Manipulées, Neufchatel.

Varine-bohan, H. (1979). Entrevista com Hugues de Varine-Bohan. In: Os Museus no Mundo. Rio de Janeiro: SALVAT Editora do Brasil. 8-21p., 70-81p.

\#MarielleVive. (2018) Recuperado em https://www.mariellefranco.com.br . 


\begin{abstract}
Autores
Carlos Serrano Ferreira - Doutorando em Ciência Política, no ISCSP da Universidade de Lisboa, com projeto de investigação ligado ao grupo "Política e Governo" do Centro de Administração e Políticas Públicas (ISCSP), Mestre em Ciência Política pela Universidade Lusófona, especialista em Relações Internacionais pela Universidade Candido Mendes e graduado em Ciências Sociais pela Universidade Federal Fluminense. Cientista Político, ViceCoordenador do LEHC/UFRJ - Laboratório de Estudos sobre Hegemonia e Contra-Hegemonia da UFRJ. Integrante do Coletivo Andorinha - Frente Democrática Brasileira de Lisboa.
\end{abstract}

Moana Soto - Doutoranda e Mestre em Museologia pela Universidade Lusófona de Humanidades e Tecnologias, especialista em Educación y Museos pela Universidad Europea Miguel de Cervantes e graduada em Pedagogia pela Pontifícia Universidade Católica do Rio de Janeiro. Museóloga e Pesquisadora da Divisão de Memória Institucional da Universidade Federal do Rio de Janeiro. Integrante do grupo de implantação do Sistema Integrado de Museus, Arquivos e Patrimônio Cultural da UFRJ. Membro integrante do MINOM-ICOM Internacional. Coordenadora do projeto EducaMuseu. Integrante do Coletivo Andorinha - Frente Democrática Brasileira de Lisboa. 
